\title{
Developing the Resilience of Pressure Index on Islamic Banking in Indonesia
}

\author{
Satria Malik ${ }^{\mathrm{a}, *}$ \\ ${ }^{a}$ Researcher at International Program for Islamic Economics and Finance, \\ Department of Development Economics, Faculty of Economics and Business, \\ Universitas Muhammadiyah Yogyakarta
}

\begin{abstract}
Islamic banking is a component of financial institutions and the global financial system. Although the size of Islamic banking with conventional banking is smaller, the vulnerability in Islamic banking always within it. This is due to the presence of various financial risks that follow the credit cycle. Besides that, there is no one who concludes clearly that Islamic banking is more resilient than conventional banking. Therefore, some regulations need to be issued to maintain the balance and adaptive aspects of Islamic banking resilience. So that this research aims to measure the optimal level of pressure because of financing activities. This research uses an early warning system approach to estimate optimal pressure levels in Islamic banking caused by funding activities using monthly data from 2010 to 2018. The findings of this research indicate that the optimal level of pressure in Islamic banking is basically to maintain a certain financing risk and provide an optimal level caused by external shocks. This research found that the optimal level of pressure is between -0.41 to 0.08 . Finally, this research concludes that the resilience of Islamic banking in Indonesia requires a balanced asset-financing allocation by lowering non-performing financing, increasing liquid assets, and sound capital adequacy.
\end{abstract}

Keywords: Islamic banking; resilience; index; optimal level of pressure; Indonesia JEL Classification: G21; G32

\footnotetext{
${ }^{*}$ Corresponding Author: Faculty of Economics and Business, University Muhammadiyah of Yogyakarta, Jl. Brawijaya, Kasihan, Bantul Yogyakarta 55183, Indonesia. Phone: +62-274-387656, Fax: +62-274-387646. E-mail: satria_malik01@yahoo.com.
} 


\section{Introduction}

Indonesia as a Muslim country with the largest population in the worlds will become a pioneer and center for the development of finance in the world. Because, if we look the potential of Indonesia to become "global player" of Islamic finance is very large, cause: (i) the largest of the Muslim population is potential will be a customer of the Islamic financial industry; (ii) the relatively high economic growth (the range $5 \%-6,5 \%$ ) supported by the stability of economic; (iii) the increasing Indonesia's rating sovereign credit to investment grade which will increase investor interest in investing in the domestic financial sector, including the Islamic financial industry; and (iv) Indonesia has abundant natural resources that can be used as underlying assets for transactions in the Islamic financial industry (Alamsyah, 2012).

The enormous potential for Indonesia to become a "global player" in the world is also supported by the high growth of Islamic banking assets. The growth of Islamic banking assets in Indonesia is quite high, demanding that Islamic banking would be strong and resilient to various shocks that they can improve economic welfare, given that banks are central to the process of financial intermediation in the economy. According to Financial Authorities in Indonesia (Otoritas Jasa Keuangan [OJK]), (2019), the composition of assets of financial institutions indicates that the banking system is the main function of the financial system, in particular, the Commercial Bank (41\%), but the total assets of Islamic banking Commercial Bank in Indonesia are $2 \%$.

The growth of Islamic banking in Indonesia, especially in the share of assets and the performance of financial ratios of the Islamic banking industry, makes Islamic banking institutions vulnerable to the systemic risk compared to other institutions (Wiranatakusuma, 2017). Systemic risk begins with the emergence of shock and vulnerability so that it interacts with each other. If it's no balanced with an adequate level of resilience, there will be a systemic risk in Islamic banking.

The relationship between vulnerability and shock explains that Islamic banking does not resilience or conditions have a vulnerability that triggers shocks that lead to imbalances on indicators in Islamic banking. Indicators in Islamic banking will provide risk transmission on the Islamic banking balance so that it is usually called the build-up phase. In preventing build-up phase conditions, a series of monitoring indicators are needed and methods for measuring risk that is able to capture signal imbalances and can assess potential losses.

This research is motivated by the idea of developing and maintaining the resilience of pressure index on Islamic banking. Resilience is determined by the ability of Islamic banking to withstand shocks and continue to provide economic functions. Both of these conditions can be related to the evolution of systemic risk which affects the evolution of the financial cycle. Systemic risk began to emerge when there were shock and vulnerability from both internal and external Islamic banking. If the systemic risk cannot be properly mitigated, it will arise and have an impact on the financial crisis. In addition, based on several previous research 
that systemic risk has a very bad impact on economic growth. So that this research wants to give a new reference in determining policies for policymakers to be able to keep up financial system stability specifically the banking system so that it can have a positive impact on economic growth.

\section{Literature Review}

\subsection{The Resilience of Islamic Banking}

The term banking resilience is often mentioned by the Central Bank in designing and developing prudential policies and regulations. The definition of "resilience" has a very broad meaning. Banking resilience is the ability of banks to adapt and recognize through system and policies due to external shocks. Rose and Spiegel (2009) define resilience as the ability to absorb interference without changing its state. Resilience has several main characteristics, namely reducing the likelihood of failure that refers to mitigation measures, reduce the consequences of failure, and reduced the time to recover. This trait explains the role of resilience in dealing with inherent and adaptive capabilities.

Briguglio et al. (2008), banking resilience basically includes two elements, namely; (i) the ability of banks to recover quickly after external shocks that have a negative impact on banking (shock counteraction); and (ii) the ability of banks to be able to withstand shock absorption. So that to achieve this resilience there needs to be a clear understanding off what the pressure index will measure.

Yalesperdani et al. (2016), explained the resilience of capital and liquidity of the banking industry in the face of external shocks. Every banking must have strong capital quality and quantity requires good quality management through long-term funding sources to build the banking industry's resilience. Capital and liquidity factors are the factors that form the basis of resilience. Other factors such as asset quality and exchange rate risk affect both factors. The pillar of resilience is explained into five parameters, namely; (i) liquidity and funding; (ii) capital; (iii) asset quality; (iv) currency risk; and (v) earning capacity.

The main focus in the liquidity parameter is the extent to which the liquidity and funding of the banking industry are resilient in meeting short-term obligations and supporting banking business activities. Including the structure of banking funding to see the stability of funding. While the capital parameter is to assess the resilience of the banking system which is reflected by capital and various factors that influence capital, such as earning capacity, the development of productive asset quality and the risk of banking exchange rates that can affect bank capital.

\subsection{Theoretical Model}

The development of Islamic finance in Indonesia shows a good movement. This indicated by the increase in financial assets, the increasing number of products, awareness, and understanding of Islamic finance among actors and the society is 
increasing, as well as an increasingly comprehensive regulatory framework. The development of Islamic finance in Indonesia needs to optimize the full potential of Islamic finance in each sector, namely; Islamic banking, the Islamic capital market, and the Islamic non-bank financial industry. Integrated development synergy is expected to open opportunities. And enlarge the role of the Islamic finance market in the financial industry.

One of the Islamic finance industries is Islamic banking. The growth of Islamic banking in Indonesia must be able to deal with internal and external shocks. The magnitude of these shocks has made Islamic banking require special supervision to get resilience. The unpredictable world of macroeconomic conditions and less stable conditions are real challenges for the performance, stability, and resilience of banks in Indonesia specifically Islamic banking.

The external variables of Islamic banking that can trigger and worsen the vulnerability and decrease the resilience level of Islamic banking can be indicated from the level of resilience are gross domestic product (GDP), exchange rate (ER) and inflation rate (IR). The internal variables of macro-prudential indicators: return on assets (ROA), capital adequacy ratio (CAR), and liquid assets (LA). The external variables of the micro-prudential indicator: non-performing financing (NPF). ROA indicates the profitability of Islamic banking; CAR relates to a bank's capital and LA correlates to the amount of liquid assets over the total assets. The normal resilience level of Islamic banking can be seen from those previous variables mentioned. Therefore, macroeconomic conditions and the resilience of Islamic banking are very urgent to be mentioned so that they can be stable, otherwise, the banking crisis sill emerge.

\section{Method}

\subsection{Data}

The objective of this research is selected macro-prudential and micro-prudential variables to develop and maintain the resilience of the pressure index of Islamic banking in Indonesia. Based on how to obtain the data, the type of data in this research is secondary monthly time series data starting from January 2010 until 2018. The usage of monthly data based on technical statistics consideration related to the limitation of publication, while the selected time period of data from 2010 until 2018 based on a new phase of new normal of the global economy especially in Indonesia. This new normal occurs after one cycle of the business cycle (expansion, peak, recession, trough, and recovery phase). The data obtained from Sharia Banking Statistics (SPS) of Financial Services Authority (OJK), Central Bureau of Statistics (Badan Pusat Statistik [BPS]), a monthly report from Indonesian Financial Economics Statistics (SEKI) of Central Bank of Indonesia (BI), and other available resources. This research used four variables as the independent variables selected macro-prudential indicators; return on assets (ROA), capital adequacy ratio (CAR), and liquid assets (LA) and micro-prudential indicators; 


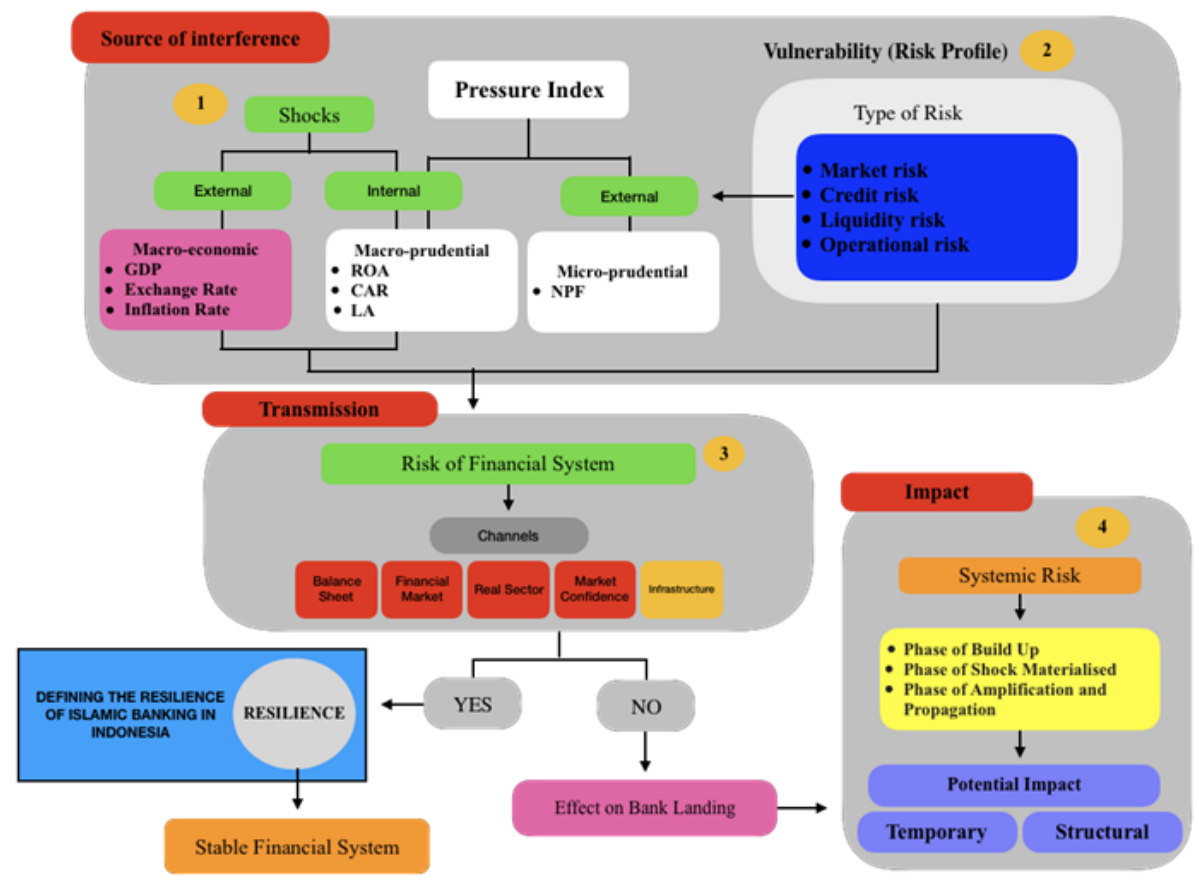

Figure 1: Conceptual of Research Framework

non-performing financing (NPF).

\subsection{Analysis Methods}

\subsubsection{Developing the Resilience of Islamic Banking Index}

The pressure index is a tool used to compare performance in analyzing policy and public communication. In general, the pressure index provides a simple comparison that can be used to describe the complex problem and sometimes very difficult to understand in a broad field. The indicators developing the pressure index are divided into two types, namely quantitative and qualitative obtained from the fact that observations are relatively in a certain area. When evaluated at regular intervals it will show the direction of change in different units and through time. Pressure index based on the underlying model Saisana and Tarantola (2002) explained some of the main explanations pro and con using pressure indicators, as presented in Table 1. 
Table 1: Pros and Cons of Pressure Indicators

\begin{tabular}{ll}
\hline Pros: & Cons: \\
\hline $\begin{array}{l}\text { Can summarise complex, multidimensional } \\
\text { realities with a view to supporting decision- } \\
\text { makers }\end{array}$ & $\begin{array}{l}\text { May send misleading policy messages if poorly } \\
\text { constructed or misinterpreted }\end{array}$ \\
\hline $\begin{array}{l}\text { Are easier to interpret than a battery of many } \\
\text { separate indicators. }\end{array}$ & May invite simplistic policy conclusions \\
\hline Can assess the progress of countries over time & $\begin{array}{l}\text { Maybe misused to support the desired policy, } \\
\text { if the developing process is not transparent } \\
\text { and/or lacks sound statistical or conceptual } \\
\text { principles. }\end{array}$ \\
\hline $\begin{array}{l}\text { Reduce the visible size of a set of indicators } \\
\text { without dropping the underlying information } \\
\text { base }\end{array}$ & $\begin{array}{l}\text { The selection of indicators and weights could } \\
\text { be the subject of political dispute }\end{array}$ \\
\hline $\begin{array}{l}\text { Thus, making it possible to include more infor- } \\
\text { mation within the existing size limit }\end{array}$ & $\begin{array}{l}\text { May disguise serious failings in some index } \\
\text { and increase the difficulty of identifying proper } \\
\text { remedial action if the developing process is not } \\
\text { transparent }\end{array}$ \\
\hline $\begin{array}{l}\text { Place issues of country performance and } \\
\text { progress at the center of the policy arena }\end{array}$ & $\begin{array}{l}\text { May lead to inappropriate policies if the index } \\
\text { of performance that is difficult to measure are } \\
\text { ignored }\end{array}$ \\
\hline $\begin{array}{l}\text { Facilitate communication with the general pub- } \\
\text { lic and promote accountability. }\end{array}$ & \\
\hline $\begin{array}{l}\text { Help to construct/underpin narratives for lay } \\
\text { and literate audiences }\end{array}$ & \\
\hline $\begin{array}{l}\text { Enable users to compare complex index effec- } \\
\text { tively }\end{array}$ & \\
\hline $\begin{array}{l}\text { Source: Saisana and Tarantola (2002) } \\
\end{array}$ & \\
\hline
\end{tabular}

\subsubsection{Steps for Developing the Resilience of Islamic Banking}

This research explained an ideal sequence of seven steps for developing the resilience of the Islamic banking index, from the development of the theoretical framework to presentation and determination of the resilience of Islamic banking. Table 2 discusses the following steps for developing of pressure index.

According to Table 2 steps for developing the resilience of Islamic banking, this subsection concerning how to design, develop, and determine a measuring and maintaining the resilience of Islamic banking in Indonesia.The step is considered a methodological part of testing the resilience of Islamic banking in Indonesia. To avoid misinterpretation of data and validity, there needs to be transparency in the methodology before developing and using a pressure index.

\section{Data Selection}

The pressure index consists of several variables that represent the level of pressure in Islamic banking because of the inability to fulfill debt obligations by looking at the payment capacity, capital requirements, profitability, and liquidity position. These variables are NPF, CAR, ROA, and LA. The pressure starts to emerge when the risks that occur are piled up, thus indicating a bubble in the price of assets. 
Table 2: Pros and Cons of Pressure Indicators

\begin{tabular}{cll}
\hline No & Step: & Reason \\
\hline 1 & Theoretical Framework: & $\begin{array}{l}\bullet \text { To get a clear understanding and defini- } \\
\text { tion of the multidimensional phenomenon } \\
\text { to be measured. }\end{array}$ \\
& $\begin{array}{ll}\text { Provides the basis for the selection and com- } \\
\text { bination of variables into a meaningful com- } \\
\text { posite index under a fitness for purpose }\end{array}$ & $\begin{array}{l}\text { - To structure the various sub-groups of the } \\
\text { phenomenon. }\end{array}$
\end{tabular}
posite index under a fitness for purpose principle

- To compile a list of selection criteria for the underlying variables.

2 Data Selection: $\quad$ To check the quality of the available indicators.

Should be based on the analytical soundness, measurability, country coverage, and relevance of the indicators of the phenomenon being measured and relationship to each other.

- To discuss the strengths and weaknesses of each selected indicator.

- To create a summary table on data characteristics.

3 Normalization:

- To select suitable normalization procedures that respect both the theoretical framework and the data properties.

Should be carried out to render the variables - To discuss the presence of outliers in the comparable. dataset as they may become unintended benchmarks.

- To make scale adjustments, if necessary.

- To transform highly skewed indicators, if necessary.

$4 \quad$ Weighting and aggregation: $\quad$ - To select appropriate weighting and aggregation procedures that respect both the theoretical framework and the data properties.

Should be done along the lines of the under- $\quad$ To discuss whether correlation issues lying theoretical framework. among indicators should be accounted for. To discuss whether compensability among indicators should be allowed.

Source: Organisation for Economic Co-Operation and Development (2008)

Asset prices are adjusted to fundamental economic values and deleveraging occurs. During the deleveraging phase, asset price continues to bubble up and explode resulting in loan losses resulting in a decrease in asset values against liabilities. From a balance sheet perspective, deleveraging will have an impact on decreasing net worth capital of banks. Less capital will cause banks to reduce their loans and send messages about higher bank vulnerabilities, and causing depositor withdrawal. Fewer funds mean fewer loans and overall bad credit, causing the economy to collapse.

The characteristic of the selected variables for measuring the resilience of Islamic banking, the quality variables for the basic data are important. The selection of basic should maximize the overall quality of the final result. To obtain 
the best quality variables for the basic data, this research utilizes an early warning system; specifically, a non-parametric approach.

The technique was introduced by Kaminsky et al. (1997), the non- parametric early warning system model. The aim to evaluate the ability of selected leading indicators to signal a future currency crisis. Technically, the signal extraction approach employs a matrix indicator to build and imbalances indicator model. To identify imbalances, a matrix signal framework is used. Based on the crisis-signal framework matrix, the determination of signals based on detecting variables that are initially from defining signals and crises. Signal and crises are generated when there is an increase above the threshold level that tends to be associated with historical stress episodes.

\section{Developing a Theoretical Framework}

A sound theoretical framework is the starting point for developing of pressure index. The framework must clearly define the phenomena to be measured and its sub-components. Selecting each indicator and its weight must reflect the interests and index of the pressure index as a whole. This process should be based on what you want to measure, not on which indicators are available.

Variables are measure built from processes that have represented at a certain point based on perceptions and real conditions consistent with certain individual indicators. These variables are in the form of absolute scores, which are then converted into individual indicators or a single index. This research uses four variables, including:

$$
\begin{aligned}
& N P F_{t}=\left(\frac{\text { Non Performing Financing }}{\text { Total Financing }_{t}}\right) * 100 \% \\
& C A R_{t}=\frac{\text { Capital }_{t}}{\text { Risk Weighted Asset }}+100 \%
\end{aligned}
$$

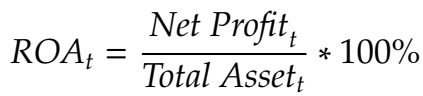

$$
\begin{aligned}
& L A_{t}=\frac{\text { Cash }_{t}+\text { Reserve Requirement }_{t}+\text { Placement in Both Banks }_{t}+\text { Investment in Securities }_{t}}{\text { Total Asset }_{t}} * 100 \%
\end{aligned}
$$

The individual index is the basis for evaluating relationships with specific objectives which can imply a number of individual indexes. This is a function that states each variable with another variable that shows its desires according to the expected consequences associated with the same goal. To developing a pressure index of variables is needed before any data aggregation, because indicators in 
datasets often have different measurement units.

$$
I_{i t}=\frac{\left(X_{i t}-\bar{X}_{i}\right)}{\sigma_{i}}
$$

Where:

$I_{i t}$ : The value of a single index of variable $i$ at time $t$;

$X_{i t}$ : Value of a variable $i$ at time $t$;

$\bar{X}_{i}$ : Average value of variable $i$;

$\sigma_{i}$ : Standard deviation of variable $i$.

A pressure index is an aggregate of all individual indicators used to explain the resilience of Islamic banking. The pressure indicators consist of individual indices. In this research, the pressure index constructed by aggregated a weighted individual index.

$$
\begin{gathered}
\text { Composite Index } t=W * \text { Pressure Index }_{t} \\
\text { Pressure Index }_{t}=\left(W * I N P F_{t}+W * R O A_{t}+W * I C A R_{t}+W * I L A_{t}\right)
\end{gathered}
$$

Where:

$W$ : Weighted index;

$t$ : Time.

\section{Normalization}

A pressure index is a way to deduce complex phenomena, but almost every individual pressure has different measurements. Therefore, there is a need for variables that have the same measurements to avoid figuratively trying to add other variables. There are several normalization methods that can be used, one of which is standardization. The standardization method is careful information retrieval based on an absolute level, the presence of extreme values and the variance in each variable.

The standardization method applies for the purpose of maintaining marginal changes and extreme variable values. To identify the resilience of Islamic banking, it necessary to capture extreme values and marginal changes to detect levels of resilience over time. In addition, this method can represent changes in up and down in a variable value, where if the change is more significant at the lower variable level, then the data must go down, and vice versa.

$$
I_{i}^{t}=\frac{\left(X_{i}^{t}-\bar{X}_{i}^{t}\right)}{\sigma_{i}^{t}}
$$

Where:

$X_{i}^{t}$ : Each variable;

$\bar{X}_{i}^{t}$ : The average individual variable;

$\sigma_{i}^{t}:$ Standard deviation. 
The standardization method is the most commonly used because it converts all variables to a common scale with an average of 0 and a standard deviation of 1 . The average of 0 means that the standardization avoids introducing aggregation distortions stemming from differences in the variables mean. The average of 0 means that the standardization avoids introducing aggregation distortions stemming from differences in the variables means. The scaling factor is the standard deviation of the indicator across the period of observation.

\section{Weighting and Aggregation}

This research uses the unobserved components model (UCM) as the weighting method, which has the strength that weights do not depend on ad hoc restrictions, meaning it is data-driven. According to the Organisation for Economic Co-Operation and Development (2008), the unobserved components model is assumed to depend on an unobserved variable plus an error term. Therefore, estimating the unknown component sheds some light on the relationship between the pressure and its components. The weight obtained will be set to minimize the error in the pressure.

\section{Uncertainty and Sensitivity}

Pressure indicator development involves stages where subjective judgments have to be made; the selection of individual indicators, the choice of aggregation model and the weights of the indicators. All these subjective choices are the bones of the pressure indicator and, together with the information provided by the numbers themselves, shape the message communicated by the pressure indicator. Therefore, the sensitivity analysis performs an "X-rays" of the model by studying the relationship between the index and pressure indicators.

More specifically, sensitivity analysis is the research of how the variation in the output can be apportioned, qualitatively or quantitatively, to different sources of variation in the assumptions, and of how the given pressure indicator depends upon the information fed into it. Sensitivity analysis is thus closely related to uncertainty analysis, which aims to quantify the overall uncertainty in the pressure index as a result of the uncertainties in the model input.

\section{Back to The Data}

Back to the data basically to deconstruct of pressure index that can help extend the analysis. Pressure index indicators provide a starting point for the analysis. While they can be used as summary indicators to guide policy and data work, they can also be decomposed in such a way that the contribution of the subcomponents (individual) variables can be identified well. 


\section{Visualization of the Resilience of Islamic Banking}

Visualization of the resilience of the Islamic banking index must be able to communicate a story to decision-makers and other end users quickly and accurately.

According to Figure 2, there are three aspects of the resilience of Islamic banking, namely: (1) related to the optimum level of resilience, which indicates the range in which system sustainability. The highest level of resilience is reflected in Islamic banking's ability to absorb shocks while still providing economic services; (2) where Islamic banking is prone to a crash. This condition, Islamic banking can act as a shock transmitter because its operations are characterized by higher lending, less capital, less liquidity, higher competition and less diversified lending allocation. These conditions make the banking system unsustainable; and (3) where Islamic banking tends to stagnate as it becomes too prudent with respect to resisting shocks and neglects its economic services. The stagnation is characterized by lower lending, higher capital and liquidity adequacy, lower competition and a highly diversified lending allocation.

Optimum Level for Resilience:

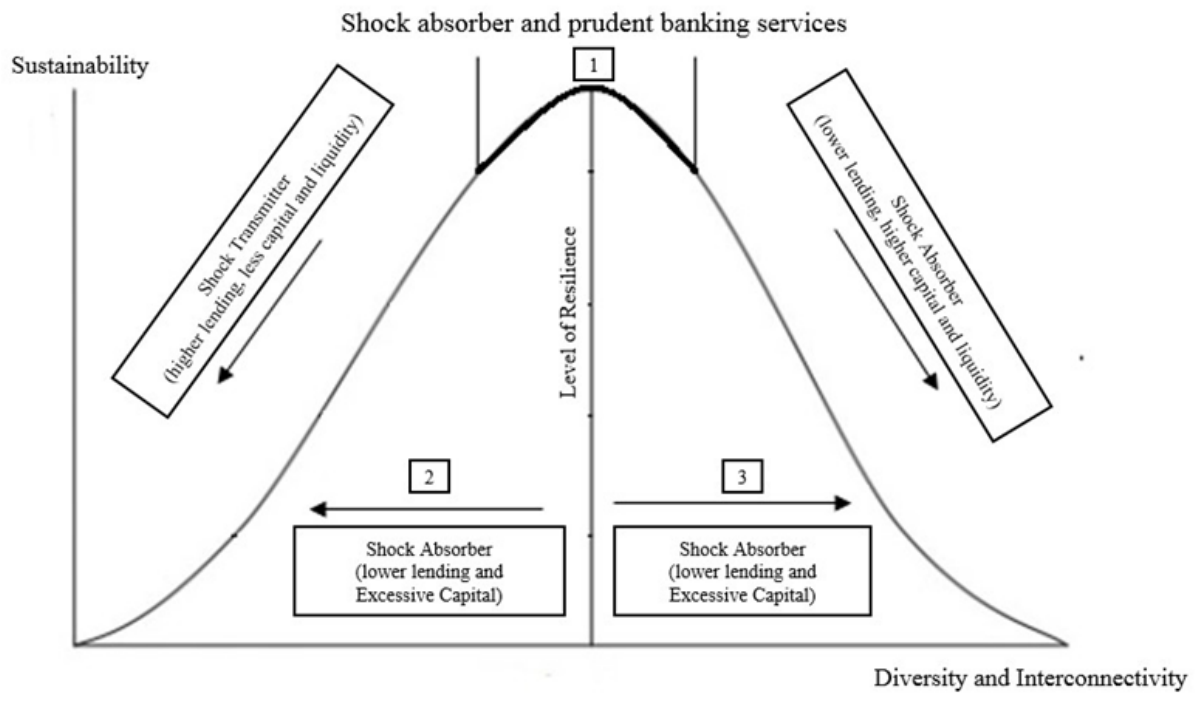

Figure 2: The Optimum Level of the Resilience of Islamic Banking 


\section{Result}

\subsection{Developing a Theoretical Framework}

The resilience of the banking sector depends on cycle conditions, and whether it is in a leveraging or deleveraging phase. However, the banking sector problems start to build-up in the leveraging phase and continue to materialize if they are not appropriately addressed. Therefore, the period or episode that evolves into a systemic crisis should be identified. To identify the period where the leveraging is about to start, the year with the lowest standard deviation is determined (Ogawa and Shimizu, 2011). The selected year is considered to be the base year where there is a fundamental equilibrium and the deviation of all individual indices is a small as possible. This research, the year 2017 is selected as the base year. The base year implies that the development of Islamic banking is in a new normal period or a period where leveraging is about to start.

\subsection{Data selection}

The selection of data must maximize the overall data quality which describes the resilience of Islamic banking as a composite indicator. As shown in Figure 3, the resilience of Islamic banking is developing on four variables, which represent the pressure index. The pressure index consists of several variables that represent the level of pressure in Islamic banking because of the inability to fulfill debt obligations by looking at the payment capacity, capital requirements, profitability, and liquidity position. These variables are NPF, CAR, ROA and LA.

As demonstrated in Figure 3, there are four stages of pressure index that indicate the level of solvency of a bank responding to upcoming shocks in a financial system, namely; (i) refers to a condition where risk or shock will accumulate in the banking sector and financial system; (ii) shock continues to build up, and risks in the banking sector begin to materialize, showing higher pressure; (iii) the shock manifested in the financial system and deteriorating risk before it materialized in the banking sector, indicating a higher pressure level; (iv) as a result of the absence of mitigating policies, or shortcomings in policies or procedures, both shocks and risks propagate and amplify across throughout the system. At this stage, the bankruptcy occurred because of severe financial distress.

Based on this explanation, banking activities must reach a level of sustainability that shows the level of pressure, risk, and shock that is optimally absorbed. Therefore, the optimal level must be applied to those four variables, so that they can support the attainment of level sustainability with respect to the level of resilience of Islamic banking.

\subsection{Normalization}

As illustrated in Table 3, each individual variable is transformed into a pressure index according to its index using the standardization method. The year 2017 


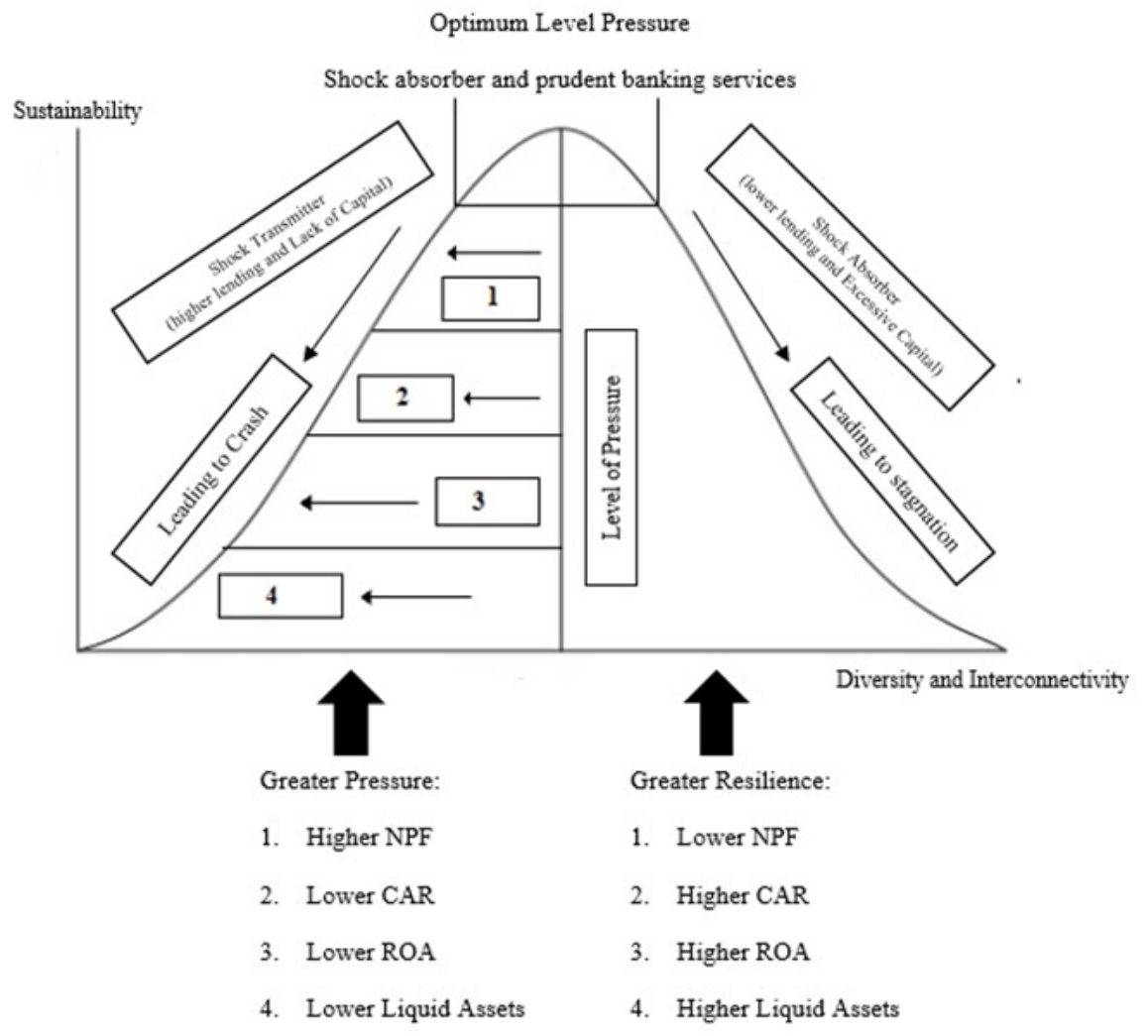

Figure 3: The Performance of the Pressure Variable Affecting the Resilience of Islamic Banking

is used as the reference year or base year, which can then be used to measure the level of deviation and extreme values of the overall variable index. Thus, the output of the standardization variables is used to aggregate and developing the pressure index.

Table 3: The Summary of the Quality Index of Pressure Index

\begin{tabular}{ccc}
\hline \multicolumn{2}{c}{ Standard Method with Base Year 2017 for Indexation (I) } \\
\hline Aggregate Index & Dimensional Index & Individual Indices \\
\hline & & INPF \\
Composite Index & Pressure Index & IROA \\
& & ICAR \\
& ILA \\
\hline
\end{tabular}




\subsection{Weighting and Aggregation}

As shown in Table 4, every component for developing a pressure index has its own weighted index. IROA is variables of the pressure index that is significant and influence the value of a pressure index or reflect their economic significance. These results imply that the level of resilience of Islamic banking should consider mainly the ROA.

Table 4: The Weights of Components for Constructing Pressure Index

\begin{tabular}{ccccccc}
\hline Variable Weight & INPF & IROA & ICAR & ILA & Total & Weight \\
\hline Pressure Index & 0.12 & 0.58 & 0.23 & 0.06 & 1.00 & 0.26 \\
\hline
\end{tabular}

Table 5 shows the indexation results stemming from the normalized variables and the weighting method. The colors are used to distinguish between the resilience, crash and stagnation conditions. The conditions are obtained after being compared with their perspective levels of the threshold. In general, the number of units showing the resilience values is fewer than measurement units showing the crash and stagnation values. Overall, the resilience of Islamic banking in Indonesia over the period of observation mostly operates out of the level of resilience or embeds a higher level of vulnerability.

\subsection{Uncertainty and Sensitivity}

In this context of research, the quality pressure of the basic data, the quality of pressure indicators uses two techniques, namely estimating the optimal thresholds and its evaluation criteria for the pressure indicators.

i. Estimating Optimal Thresholds

The optimal thresholds are estimated using the following steps.

a) Computing the long-term trend for each pressure indicator by using the HP filter $(\pi) 14400$ as the smoothing parameter, since the data are on a monthly.

b) Computing the standard deviation and sample mean with the year 2017 as the base year.

c) Determining the signaling horizon. In this research, the signaling window is $3,12,18$, and 24 .

d) Setting the thresholds for the pressure indicators. In this research, the optimal thresholds are set at a multiplier $(m)$ value equal to 1,3/1,7/2,0. This multiplier is applied to estimate the values of the optimal thresholds for each index indicator.

ii. Estimating the Goodness-of-Fit Measures and Trade-offs

The goodness-of-fit measure and trade-offs are estimated using the following steps.

a) Computing the probability forecasts for event by using loss functions. In this research, the results indicate that the 3-month horizon with (m) equal to 1.3 shows the lowest loss function value. 


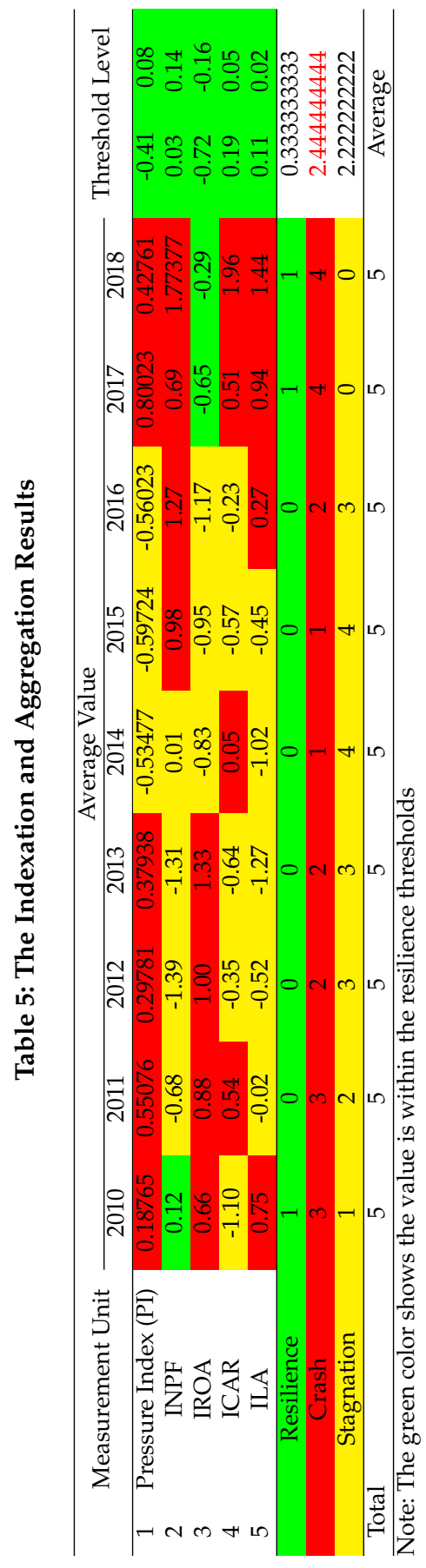


b) Evaluating the probability forecasts. In this research, the result indicates that the QPS and GSB for the 3-month time horizon show the highest percentages.

\subsection{Back to the Data}

In this research, the contribution of variables, which are divided into three distinct conditions. The conditions have been discussed previously, and indicate some potential source of a vulnerability affecting the resilience of Islamic banking. All (ROA, NPF, CAR, and LA) variables have the highest frequency of appearing to be falling into a crash and stagnation phase, and which represent 53\%, 52\%, 64\%, and $57 \%$, respectively, during the period from 2010 to 2018. Meanwhile, there is no variable represent or contribute towards the resilience of Islamic banking.

In addition, according to the minimum and maximum (min-max) analysis, the result indicates that overall the variables generally tend to locate themselves in the left-hand-side position. Assuming that their locations are based on the threshold set for every variable. The min-max values will indicate a particular range where a variable can usually be found. The left-hand side clearly shows a range in which where Islamic banking behaves in a too-excessive manner, thus leading to a crash. In contrast, the right-hand side shows a range where Islamic banking is too less to serve its economic environment. This range enables the banking sector to have a higher capability of absorbing shocks but neglects its economic function leading to economic stagnation.

\subsection{Visualization of the Resilience of Islamic Banking Index}

Given the importance of the level of resilience, Table 6 shows some conditions on the extent to which an Islamic bank operates under the levels of resilience, crash, and stagnation. These conditions are expected to provide on the current resilience of Islamic banking based on the pressure index and to detect some potential vulnerabilities to be appropriately further addressed by policymakers.

Table 6: The Threshold Level for the Resilience of Islamic Banking and Its Components

\begin{tabular}{|c|c|c|c|c|}
\hline \multirow[t]{2}{*}{ No } & \multirow{2}{*}{$\begin{array}{l}\text { Unit of } \\
\text { Measurement }\end{array}$} & \multicolumn{3}{|c|}{ Conditional Criteria } \\
\hline & & $\begin{array}{l}\text { Threshold Level of } \\
\text { Resilience }\end{array}$ & $\begin{array}{l}\text { Threshold Level of } \\
\text { Crash }\end{array}$ & $\begin{array}{l}\text { Threshold Level of } \\
\text { Stagnation }\end{array}$ \\
\hline \multicolumn{5}{|c|}{ Pressure Indicator } \\
\hline 1 & Pressure Index & $-0.41<\mathrm{PI}<0.08$ & $\mathrm{PI}>0.08$ & $\mathrm{PI}<-0.41$ \\
\hline \multicolumn{5}{|c|}{ Individual Variable } \\
\hline 2 & NPF (\%) & $4.30<\mathrm{NPF}<5.19$ & $\mathrm{NPF}>5.19$ & $\mathrm{NPF}<4.30$ \\
\hline 3 & ROA (\%) & $0.61<\mathrm{ROA}<1.18$ & $\mathrm{ROA}>1.18$ & $\mathrm{ROA}<0.61$ \\
\hline 4 & CAR (\%) & $16.14<$ CAR $<17.42$ & CAR $>17.42$ & CAR $<16.14$ \\
\hline 5 & LA (Ratio) & $0.24<\mathrm{LA}<0.28$ & $\mathrm{LA}>0.28$ & $\mathrm{LA}<0.24$ \\
\hline
\end{tabular}

Finally, Table 7 shows the threshold level, the level of resilience can be max- 
imized and the probability of systemic risk can be minimized. Therefore, the resilience of Islamic banking depends on the ability of policymakers and bankers to maintain its operations within the stated threshold levels for resilience.

Table 7: The Level of Resilience of Islamic Banking and Its Components under the Thresholds of Resilience

\begin{tabular}{lllccc}
\hline \multirow{2}{*}{ No $\begin{array}{l}\text { Unit of } \\
\text { Measurement }\end{array}$} & \multicolumn{4}{c}{ Conditional Criteria } \\
\cline { 3 - 6 } & $\begin{array}{l}\text { Threshold Level of } \\
\text { Resilience }\end{array}$ & $\begin{array}{l}\text { Level of Re- } \\
\text { silience }\end{array}$ & $\begin{array}{l}\text { Probability of } \\
\text { Fragile }\end{array}$ & $\begin{array}{l}\text { Probability of } \\
\text { Systemic Risk }\end{array}$ \\
\hline & & \multicolumn{4}{c}{ Pressure Indicator } \\
1 & Pressure Index & $-0.41<\mathrm{PI}<0.08$ & $0.92-0.98$ & $0.51-0.77$ & $0.23-0.49$ \\
\hline \multicolumn{5}{c}{ Individual Variable } \\
2 & NPF (\%) & $4.30<\mathrm{NPF}<5.19$ & $0.92-0.94$ & $0.00-0.30$ & $0.70-1.00$ \\
3 & ROA (\%) & $0.61<\mathrm{ROA}<1.18$ & $0.91-0.94$ & $0.69-0.94$ & $0.06-0.31$ \\
4 & CAR (\%) & $16.14<\mathrm{CAR}<17.42$ & $0.91-0.97$ & $0.09-0.18$ & $0.82-0.91$ \\
5 & LA (Ratio) & $0.24<\mathrm{LA}<0.28$ & $0.92-0.98$ & $0.00-0.29$ & $0.71-1.00$ \\
\hline
\end{tabular}

\section{Conclusions}

In summary, the main purpose of the current research was to developing of pressure index and maintaining the resilience of Islamic banking in Indonesia found out result, as follows:

1. The resilience of Islamic banking was measured by developing the resilience of Islamic banking in an index. Practically, the resilience of the Islamic banking index is used as a proxy for determining the level of resilience. At the level of resilience index, Islamic banking in Indonesia is able to deal with shocks, which is reflected by its ability to prevent its elements from falling into both a crash and stagnation phase, thus it has the ability to facilitate the efficient allocation of financing, promote the balanced intermediation of capital and risk, and strengthen its level of efficiency.

a. The level of resilience was estimated by developing a pressure index, which was developed through seven sequential steps. The level of resilience was computed by discovering the optimal level of thresholds using a signal extraction approach within a matrix crisis signal framework.

b. The validation of developing a pressure index assessed by using some quality of basic data measurements: a measurement of the quality pressure for the basic data, a measurement of the quality basic data for the procedure for developing a pressure index, and the quality profile for the pressure index.

2. The resilience of Islamic banking also needs to consider the stability of the financial system. From a policymaker point of view, the resilience of Islamic banking is affected by external shocks, given the growth of the interlinkages and the complexity of the current financial system. Therefore, improving 
the resilience of Islamic banking is a matter of boosting banks' ability to cope with external shocks.

\subsection{Suggestion}

The resilience of Islamic banking is basically achieved when it can absorb shocks and continue to contribute to productivity and economic growth through its financial services. The level of resilience should certainly consider the level of vulnerability at a banking level as well as at the macroeconomic level. By considering both of them, the balance sheet of Islamic banking remains sound, and capable of fulfilling its financial obligations and services.

This research, the policy implication related to the resilience of Islamic banking components. The policy implications are as follows.

Table 8: The Summary of Performance of Variables and Pressure Index at an Optimal Level of Resilience

\begin{tabular}{|c|c|c|c|c|c|}
\hline No & $\begin{array}{l}\text { Variable } \\
\text { or Index }\end{array}$ & $\begin{array}{l}\text { Source of Vulnerability } \\
\text { (Crash, Stagnation, Re- } \\
\text { silience) }\end{array}$ & $\begin{array}{l}\text { Behavior in } \\
\text { a Cycle (Left } \\
\text { or Right hand } \\
\text { Side) }\end{array}$ & Impact & $\begin{array}{l}\text { Policy Impli- } \\
\text { cation }\end{array}$ \\
\hline 1 & INPF & $\begin{array}{l}\text { Crash - Resilience } \\
\text { (Source of Crash) }\end{array}$ & Left-hand side & $\begin{array}{l}\text { High Pressure } \\
\text { (Insolvency) }\end{array}$ & Lower INPF \\
\hline 2 & ICAR & $\begin{array}{l}\text { Resilience - Stagnation } \\
\text { (Source of Stagnation) }\end{array}$ & Right-hand side & $\begin{array}{l}\text { Low Pressure } \\
\text { (Solvency) }\end{array}$ & Lower ICAR \\
\hline 3 & IROA & $\begin{array}{l}\text { Resilience - Stagnation } \\
\text { (Source of Resilience) }\end{array}$ & Right-hand side & $\begin{array}{l}\text { Medium Pressure } \\
\text { (Solvency) }\end{array}$ & Lower IROA \\
\hline 4 & ILA & Resilience - Stagnation & Right-hand side & $\begin{array}{l}\text { Medium Pressure } \\
\text { (Solvency) }\end{array}$ & Lower ILA \\
\hline
\end{tabular}

\subsection{Recommendations}

This research discussed developing of pressure index and maintaining the resilience of Islamic banking in Indonesia. In addition, this research has only one feature of discussion, namely, resilience attributes of Islamic banking. Thus, to further develop and extend this research, there are two possible points for recommendation and development, as follows:

(i) The leading indicators of resilience Islamic banking, research could involve a larger number of indicators being selected as the leading indicators.

(ii) The financial cycle, given that the resilience of Islamic banking is often linked to financial cycles, it is important to research the main features of the financial cycle.

\section{References}

[1] Alamsyah, H. (2012). Perkembangan dan prospek perbankan syariah Indonesia: Tantangan dalam menyongsong MEA 2015. Disampaikan dalam Ceramah 
Ilmiah Ikatan Ahli Ekonomi Islam (IAEI), Milad ke-8 IAEI, 13 April 2012. https:/ /www.bi.go.id/id/ruang-media/pidato-dewan-gubernur/documents / 6bf00812e40b4d0cb140ea80239c4966perkembanganprospekperbankansyariahindone siamea201.pdf.

[2] Briguglio, L., Cordina, G., Farrugia, N., \& Vella, S. (2008). Economic vulnerability and resilience: Concepts and measurements. UNU-WIDER Research Paper No. 2008/55. United Nations University (UNU) - World Institute for Development Economics Research (WIDER). https://www.wider.unu.edu/publication/ economic-vulnerability-and-resilience.

[3] Kaminsky, G., Lizondo, S., \& Reinhart, C. M. (1997). Leading Indicators of Currency Crises. IMF Working Paper, WP/97/79. International Monetary Fund. https://www.imf.org/en/Publications/WP/Issues/2016/12/30/ Leading-Indicators-of-Currency-Crises-2256.

[4] Ogawa, E., \& Shimizu, J. (2011). Asian Monetary Unit and Monetary Cooperation in Asia. ADBI Working Paper Series, 275. Asian Development Bank Institute. Retrieved from https://www.adb.org/sites/default/files/publication/156130/adbi-wp275. pdf.

[5] Organisation for Economic Co-operation and Development. (2008). Handbook on constructing composite indicators: Methodology and user guide. https://www.oecd.org/els/ soc/handbookonconstructingcompositeindicatorsmethodologyanduserguide.htm.

[6] Otoritas Jasa Keuangan. (2019). Laporan Triwulanan: Triwulan I - 2019. Retrieved from https://www.ojk.go.id/id/data-dan-statistik/laporan-triwulanan/Pages/ -Laporan-Triwulan-I---2019.aspx.

[7] Rose, A. K., \& Spiegel, M. M. (2009). Cross-country causes and consequences of the 2008 crisis: International linkages and American exposure. Federal Reserve Bank of San Francisco Working Paper Series, 2009-18. Retrieved from https:/ /www.frbsf.org/ economic-research/files/wp09-18bk.pdf.

[8] Saisana, M., \& Tarantola, S. (2002). State-of-the-art report on current methodologies and practices for composite indicator development. EUR 20408 EN. Ispra, Italy: European Commission, Joint Research Centre, Institute for the Protection and the Security of the Citizen, Technological and Economic Risk Management.

[9] Wiranatakusuma, D. B. (2017). An inquiry into resilience of Islamic Banking in Indonesia (Doctoral Dissertation, International Islamic University Malaysia).

[10] Yalesperdani, D., Birowo, A. W., Robinson, I., Fitriany, Sinartha, I. N. Y., \& Putra, E. (2016). Bank Industry Rating dan Risk Register: Tools Pengawasan Makroprudensial Bank Indonesia. Kajian Stabilitas Keuangan, 26, 223-233. 
this page intentionally left blank 